\title{
Dependence of the severity of the systemic inflammatory response on resistance to hypoxia in male Wistar rats
}

This article was published in the following Dove Medical Press journal: Journal of Inflammation Research

\section{Dzhuliia Sh Dzhalilova' \\ Anna M Kosyreva' Mikhail E Diatroptov' \\ Elena A Ponomarenko' Ivan S Tsvetkov' Natalia A Zolotova' Vladimir A Mkhitarov ${ }^{2}$ Dmitry N Khochanskiy' Olga V Makarova'}

'Department of Immunomorphology of Inflammation, Federal State Budgetary Institution "Science Research Institute of Human Morphology", Moscow, Russia; 2Department of Informatics and Morphometry, Federal State Budgetary Institution "Science Research Institute of Human Morphology”, Moscow, Russia
Correspondence: Dzhuliia Sh Dzhalilova Department of Immunomorphology of Inflammation, Federal State Budgetary Institution "Science Research Institute of Human Morphology", Tsyryupa Str., 3,

II 7418 Moscow, Russia

Tel +7906 7157024

$\mathrm{Fax}+74991208065$

Email juliajal93@mail.ru
Purpose: The aim of the study was to characterize the severity of the systemic inflammatory response induced by lipopolysaccharide (LPS) in animals with different resistance levels to hypoxia.

Materials and methods: Two to three months old male Wistar rats (220-240 g) were divided according to hypoxia tolerance in a hypobaric chamber. After a month, they were injected intraperitoneally with Escherichia coli LPS at a dose of $1.5 \mathrm{mg} / \mathrm{kg}$. After 3, 6 and 24 hours of LPS injection, we studied the levels of IL-1 $\beta$, C-reactive protein (CRP) and TGF- $\beta$ in the serum, the expression of $H i f-1 \alpha$ and $N f-\kappa b$ in the liver, morphological disorders in the lung and ex vivo production of IL-10 by splenic cells activated by ConA.

Results: In the early periods after the injection of LPS, increase in $N f-k b$ expression in the liver was observed only in the rats susceptible to hypoxia. After 6 hours of LPS injection, the number of neutrophils in the interalveolar septa of the lungs of rats susceptible to hypoxia was higher than in tolerant rats. This points to the development of more pronounced LPS-induced inflammation in the rats susceptible to hypoxia and is accompanied by increased expression of Hif- $1 \alpha$ in the liver after 6 hours of LPS administration, serum IL- $1 \beta$ level after 3 hours and CRP level after 24 hours. The production of the anti-inflammatory cytokine IL-10 by the spleen was significantly decreased after 6 hours of LPS injection only in the animals tolerant to hypoxia. After 24 hours of LPS injection, a significant decrease in serum TGF- $\beta$ level occurred in the rats tolerant to hypoxia in comparison with the control group, which improved the survival rates of the animals.

Conclusion: We have demonstrated the differences in the severity of the LPS-induced inflammatory response in male Wistar rats with different resistance levels to hypoxia. Rats susceptible to hypoxia are characterized by a more pronounced inflammatory response induced by LPS.

Keywords: tolerant, susceptible, hypoxia, inflammation, SIRS, lipopolysaccharide, Hif-1a, $N f-\kappa b$

\section{Introduction}

It is known that the severity of infectious and inflammatory diseases, including sepsis, mortality and survival rates depend on many patient-specific factors, in particular, ethnicity, age and sex. ${ }^{1-3}$ However, it remains unclear why the severity of the course, the outcome of the disease and the likelihood of secondary infections in a homogeneous population of people of the same age and sex differ. ${ }^{3}$ Perhaps, one of the factors determining these differences may be the individual characteristics of resistance to the lack of oxygen, since it is known that hypoxia develops during inflammation. 
Hypoxia is an important physiological stimulus for organisms. During adaptation to low oxygen content in cells and tissues, genes that participate in the metabolism of glucose and iron, angiogenesis and cell proliferation are activated. In eukaryotic cells, the key component responsible for the regulation of the molecular response to hypoxia is the transcription factor hypoxia-inducible factor 1 (HIF-1). ${ }^{4} \mathrm{HIF}-1$ is a heterodimeric complex consisting of two subunits, HIF- $1 \alpha$ and HIF- $1 \beta$. HIF- $1 \beta$ is constitutively present in the cells, but HIF- $1 \alpha$ is targeted for proteasomal degradation by a set of oxygen-sensing prolyl-hydroxylases (PHDs) during normoxic conditions. Due to the fact that oxygen is required as a cofactor for PHD-mediated hydroxylation of HIF- $1 \alpha$, hypoxia causes a functional inhibition of PHDs, leading to stabilization of HIF- $1 \alpha$. Under hypoxic conditions, HIF-1 $\alpha$ accumulates in the cytoplasm, translocates into the nucleus, forming a complex with HIF-1 $\beta$, and binds the hypoxiaresponse elements on the promoters of hypoxia-responsive genes, inducing their expression. ${ }^{5,6}$

Inflammation in various tissues develops local hypoxia due to microcirculatory disturbances, as well as an increase in oxygen demand of the immune cells during their infiltration into the inflammatory focus. ${ }^{7}$ Earlier, the relationship between the molecular pathways of hypoxia and inflammation was revealed. NF- $\kappa B$ influences the expression of HIF- $1 \alpha$ in both hypoxia and in response to inflammatory stimuli. The proximal part of the promoter of the HIF-1a gene contains

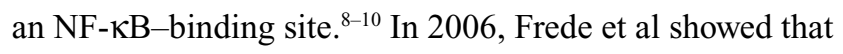
lipopolysaccharide (LPS) can induce toll-like receptor 4 (TLR-4) - and NF- $\mathrm{kB}-$ dependent increase in mRNA and HIF-1 $\alpha$ protein levels. ${ }^{11}$ It has also been demonstrated that HIF- $1 \alpha$ is stabilized by active forms of oxygen and the proinflammatory cytokine IL-1 $\beta .{ }^{12,13} \mathrm{HIF}-1 \alpha$, in turn, can activate $\mathrm{NF}-\kappa \mathrm{B}$ : it is known that inhibitors promoting the ubiquitindependent destruction of HIF- $1 \alpha$ also control the activity of the kinase complex I kappa B kinase (IKK), responsible for the regulation of NF- $\mathrm{KB} .^{14,15}$

The result of HIF-1 activation depends on the context in which it was activated (hypoxia or inflammation). If HIF-1 is elevated by hypoxia, the transcription of various targeted genes is enhanced, which makes it possible to adapt to the lack of oxygen. Being initiated by the TLR-4- and NF- - Bdependent pathways, the genes of proinflammatory cytokines become active. ${ }^{16}$ According to the literature, HIF can play both anti-inflammatory and proinflammatory roles under conditions of inflammation. ${ }^{17}$ In mice, HIF-1 was described as a protective factor in the acute colitis model: deficiency of HIF-1 $\alpha$ in animals with colitis resulted in high mortality, and in surviving mice, to more severe clinical manifestations. ${ }^{18}$ In contrast, in systemic infections such as sepsis, the increase in HIF- $1 \alpha$ levels results in greater mortality and elevated levels of proinflammatory cytokines (IL-1 $\beta$, TNF- $\alpha$ ) in the blood serum and decrease in levels of anti-inflammatory cytokine IL-10, which promotes activation of the immune response. ${ }^{19}$ The activation of HIF-1 as a potential prognostic marker of sepsis is being discussed. ${ }^{20}$

Human population, as well as other species of animals, is heterogeneous in hypoxia tolerance. ${ }^{21,22}$ The genetic polymorphism of the HIF $1 \alpha$ gene affects the severity and outcome of infectious and inflammatory diseases. For example, it is established that the polymorphism of the gene HIF $1 \alpha$ (1772T allele), which determines its high level of expression, is a risk factor for the development of abdominal aortic aneurysm and oral lichen planus. ${ }^{23,24}$ The other polymorphic HIF-1 $\alpha$ rs 12434439 GG genotype plays a protective role for rheumatoid arthritis development, ${ }^{25}$ but gene polymorphism HIF-1 $\alpha$ rs 11549467 is associated with the risk of COPD. ${ }^{26}$

It is known that laboratory animals are divided by their resistance to hypoxia. ${ }^{27-30}$ Animals that are tolerant and susceptible to hypoxia differ by many parameters (such as antioxidant activity, mitochondrial enzyme complex I activity, etc), ${ }^{31}$ including the content of HIF-1 $\alpha$. It has been demonstrated that in rats susceptible to hypoxia, under normal conditions, the level of HIF- $1 \alpha$ in the neocortex is 1.7 times higher than in tolerant rats. ${ }^{27}$ Earlier, we demonstrated that at different periods after acute hypoxic exposure, rats tolerant and susceptible to hypoxia are characterized by the variability in expression of $N f-k b$ and TGF- $\beta$ cytokine content, modulating inflammatory responses. ${ }^{32}$ This may cause the distinctive features of the development of inflammation. The obtained data indicate that animals with different tolerance levels to hypoxia have various adaptive capabilities and predisposition to the development of inflammatory diseases: in the susceptible animals, the oxidative stress marker 8-isoprostane increases after hypoxic exposure, which is associated with the damage to cellular macromolecules and increase in the level of TGF- $\beta .^{32}$

In experimental researches, one of the widespread models of inflammation is LPS-induced systemic inflammatory response syndrome (SIRS). LPS is a cell wall component of gram-negative bacteria, which is recognized by TLR-4 on the surface of immunocompetent cells. ${ }^{33,34}$ LPS is a common inflammatory stimulus in clinical and laboratory studies, and its effects on NF- $\mathrm{\kappa B}$ and inflammatory mediators have been well characterized. ${ }^{35,36}$ Injection of high doses of LPS leads to the development of severe inflammatory response, which 
manifests itself via hypercoagulation with the development of disseminated intravascular coagulation (DIC) syndrome, acute respiratory distress syndrome, vacuolar cell degeneration, dystrophic changes and necrosis in the liver and endotoxemia. ${ }^{37-39}$

Hypoxia, resulting from the microcirculatory disorders, caused by DIC plays a key role in the progression of SIRS and sepsis. ${ }^{37}$ The severity of hypoxic damage to tissues and organs not only depends on the microcirculatory disorders, but is also mostly determined by individual resistance to hypoxia, which is not taken into consideration in clinical and experimental studies.

Therefore, the aim of the study was to determine the differences in the severity of the systemic inflammatory response caused by the administration of LPS in male Wistar rats with different resistance levels to hypoxia.

\section{Materials and methods Experimental animals}

Male Wistar rats $(n=60), 2-3$ months old and weighing 220-240 g, were purchased from the animal breeding facility branch "Stolbovaya" of the Federal State Budget Institution of Science, the "Scientific Center for Biomedical Technologies of the Federal Medical and Biological Agency", Russia. Six rats per cage $(18.5 \times 60 \times 38 \mathrm{~cm})$ were housed in a temperatureregulated room under 12:12 hour light-dark cycle and relative humidity between $40 \%$ and $50 \%$ and with unlimited access to water and food ("Char", JSC "Range-Agro", Turakovo, Russia). We obtained permission from the Bioethics Committee of the Science Research Institute of Human Morphology (Protocol No. 16, November 11, 2015) for conducting the study. All manipulations with animals were carried out according to the European convention for the protection of vertebrate animals used for experimental and other scientific purposes (ets no. 123), Strasbourg, 2006, and all efforts were made to minimize the suffering and distress of animals.

\section{Determination of resistance to hypobaric hypoxia}

Hypoxic tolerance was determined by measuring the time taken for the onset of gasping. According to the literature, this parameter characterizes the organism's resistance to hypoxia. ${ }^{27-30}$ Adult male Wistar rats were exposed, one at a time, to simulated hypobaric hypoxia, equivalent to the altitude of $11,500 \mathrm{~m}$, as described previously ${ }^{27-30,32,40-42}$ in an animal decompression chamber coupled to a mercury barometer (equivalent to $180 \mathrm{mmHg}$ ). All the decompressions and recompressions were achieved gradually at the rate of $600 \mathrm{~m}$ $(\approx 40 \mathrm{mmHg}) / \mathrm{min}$ to prevent any tissue injury to the organism as a result of a sudden fall or rise in ambient pressure. The airflow in the chamber was $2 \mathrm{~L} / \mathrm{min}$, while the relative humidity was maintained at $40 \%-50 \%$. The time taken for appearance of the first sign of gasping, a characteristic hyperventilatory response, was recorded using an electronic stopwatch. Based on their gasping time, animals were categorized into three groups: normal ( $80-240$ seconds, $n=12)$, tolerant ( $>240$ seconds, $n=25)$ and susceptible ( $<80$ seconds, $n=23)$. Normal rats were not used in the experiments. After the experiment, all rats were found to be alive and to have resumed normal activity without any evident sign of pathology.

\section{Modeling of SIRS}

One month after the determination of resistance to hypoxia, ${ }^{30,42}$ rats in the experimental groups were injected intraperitoneally with LPS from Escherichia coli O26:B6 (Sigma-Aldrich, St Louis, MO, USA) at a dose of $1.5 \mathrm{mg} /$ $\mathrm{kg}$, leading to pathological changes in target organs. ${ }^{43}$ The animals were euthanized with an overdose of carbon dioxide gas using a gradual fill (30\% chamber volume per minute) technique after 3, 6 and 24 hours of LPS injection (five or eight animals for each term). The timing choice was determined by the fact that $N f-k b$ expression increased after 1-2 and 6 hours, and pronounced pathological changes in the target organs developed on the first day after the administration of LPS. ${ }^{44,45}$ In control groups, the rats tolerant $(n=5)$ and susceptible $(n=5)$ to hypoxia received an intraperitoneal injection of physiological saline.

\section{Mortality of animals from SIRS}

Within a day after the injection of LPS, some of the animals died. Mortality rates of rats in response to the injection of LPS were 3 out of $18(17 \%)$ in the susceptible to hypoxia group and 2 out of $20(10 \%)$ in the tolerant group. The mortality, caused by development of endotoxin shock, appeared within 6 hours after the injection of LPS. The choice of dose of LPS was considered and approved by the Bioethics Committee of the Science Research Institute of Human Morphology (Protocol No. 16, November 11, 2015).

\section{Real-time PCR (quantitative PCR)}

Expression of Hif-1 $a$ and $N f-\kappa b$ in the liver was analyzed by real-time quantitative reverse transcription PCR. Slices of tissue from the liver, of about $30 \mathrm{~mm}^{3}$ volume, were submerged in IntactRNA Reagent (Evrogen JSC, Moscow, Russia) immediately after harvesting, incubated overnight at $4^{\circ} \mathrm{C}$ and stored at $-80^{\circ}$ until use. Total RNA was isolated 
from the tissue samples using RNeasy Plus Mini Kit (Qiagen, Hilden, Germany) according to the manufacturer's protocol. Estimated purified RNA concentration in the eluate was $0.1 \mathrm{~g} / \mathrm{L}$; quality of the material was controlled by electrophoresis.

Reverse transcription of the total RNA to randomly primed single-stranded cDNA was done using MMLV RT Kit (Evrogen JSC); the synthesis was carried out at $39^{\circ} \mathrm{C}$ for 1 hour. After heat inactivation of the enzyme, the reaction mixture was diluted with 2 volumes of sterile RNase-free water for further use and storage; final dilution of the mixture in PCR constituted 1:250. PCRs were set in duplicates on the basis of qPCRmix-HS SYBR (Evrogen JSC) with oligonucleotide primers (custom-made by SYNTOL, Moscow, Russia) in $0.2-0.4 \mu \mathrm{M}$ final concentrations. Primers for PCR were selected using the online Primer-BLAST program in accordance with the generally accepted requirements. Structures of the oligonucleotides with symbols and descriptions of the corresponding targets are given in Table 1. Amplification with detection and digital analysis of fluorescence in real time was carried out on DT-96 Real-Time PCR Cycler (DNA-Technology JSC, Moscow, Russia) in a standard mode at $95^{\circ} \mathrm{C}$ for 5 minutes followed by the PCR cycle, consisted of: $95^{\circ} \mathrm{C}$ for 15 seconds, $62^{\circ} \mathrm{C}$ for 10 seconds + reading and $72^{\circ} \mathrm{C}$ for 20 seconds, this was repeated for 45 times. Characteristic values $(\mathrm{Cp})$ were automatically generated by nonlinear regression analysis, and the relative expression values were calculated by the approach originally introduced by $\mathrm{Pfaffl}^{46}$ using $b 2 m$ (see Table 1) as the reference target.

\section{Sample collection}

Venous blood from jugular veins ${ }^{47}$ was centrifuged for 20 minutes at $200 \times g$. The obtained serum was frozen at $-70^{\circ} \mathrm{C}$ and stored for no more than 2 months. The lungs were fixed in Carnoy's solution (60 mL ethanol, $30 \mathrm{~mL}$ chloroform and $10 \mathrm{~mL}$ glacial acetic acid) for 2 hours and were embedded in paraffin according to routine procedures. Histological sections of 4-5 $\mu \mathrm{m}$ thickness were produced and stained with H\&E (BioVitrum, Saint Petersburg, Russia).

\section{Isolation and cultivation of splenic cells}

For the isolation of splenic cells, a piece of tissue was aseptically removed from each rat, placed in Potter homogenizer containing the Roswell Park Memorial Institute (RPMI)1640 medium (PanEco, Moscow, Russia) and single-cell suspensions were prepared. The red blood cells were lysed by distilled water. To activate cytokine synthesis and secretion, we cultivated $10^{6} / \mathrm{mL}$ spleen cells in $1 \mathrm{~mL}$ of culture medium with concanavalin A (ConA) $(5 \mu \mathrm{g} / \mathrm{mL})$ for 20 hours at $37^{\circ} \mathrm{C}$ and $5 \% \mathrm{CO}_{2}$ in 24 -well cultured plates. The culture medium consisted of RPMI-1640, 5\% inactivated FBS, $2 \mathrm{mM}$ glutamine and $50 \mu \mathrm{g} / \mathrm{mL}$ gentamicin. ${ }^{48}$ The cell viability was determined by the trypan blue exclusion test.

\section{Enzyme-linked immunosorbent assay}

We estimated the concentrations of IL-1 $\beta$, C-reactive protein (CRP; Cloud-Clone Corp., Wuhan, China) and TGF- $\beta$ (eBioscience, San Diego, CA, USA) in the serum by ELISA. In the culture fluid of splenic cells, we measured the concentrations of IL-10 by ELISA test systems from Cloud-Clone Corp. For determination of the intensity of the color reaction, a microplate analyzer ANTHOS 2010 (Anthos Labtec Instruments, Vienna, Austria) was used.

\section{Morphological study}

The evaluation of histological slides was randomized and blinded. Using the light microscopic method, the number of neutrophils in the interalveolar septa of the lungs was counted in ten high-power fields of view $\left(25,000 \mu^{2}\right)$ per section, and the average number of neutrophils per slide was determined. ${ }^{49}$

\section{Statistical analysis}

Digital data were tested for normality using the Kolmogorov-Smirnov test in Statistica 8.0. To isolate the group

Table I PCR primer structures and targets definition

\begin{tabular}{|c|c|c|c|c|}
\hline Target symbol & Direction & Sequence $\left(5^{\prime}-3^{\prime}\right)$ & NCBI Ref. Seq. & Target definition \\
\hline \multirow[t]{2}{*}{$B 2 m$} & Forward & CTCGCTCGGTGACCGTGAT & \multirow[t]{2}{*}{ NM_0I25I2.2 } & \multirow[t]{2}{*}{ Rattus norvegicus $\mathrm{B} 2 \mathrm{~m}, \mathrm{mRNA}$} \\
\hline & Reverse & GGACAGATCTGACATCTCGA & & \\
\hline \multirow[t]{2}{*}{ Hif-Ia } & Forward & GAGCCTTAACCTATCTGTCA & \multirow[t]{2}{*}{ NM_024359.I } & \multirow[t]{2}{*}{ R. norvegicus Hif $\mid \alpha$, mRNA } \\
\hline & Reverse & CACAATCGTAACTGGTCAGC & & \\
\hline \multirow[t]{2}{*}{$N f-\kappa b$} & Forward & GACGATCCTTTCGGAACTG & \multirow[t]{2}{*}{ NM_00I2767II.I } & \multirow[t]{2}{*}{ R. norvegicus NfkbI, mRNA } \\
\hline & Reverse & GCATATGCCGTCCTCACAG & & \\
\hline
\end{tabular}

Abbreviations: B2m, beta-2 microglobulin; Hifl $\alpha$, hypoxia-inducible factor I alpha subunit; NfkbI, nuclear factor kappa B subunit I. 
or groups that differed from others, we used the nonparametric Mann-Whitney $U$ test and multiple comparison procedures. In cases when $P<0.05$, multiple comparison procedures were performed by the Kruskal-Wallis method. The median and IQR (Me, Low-High) were calculated for values of the measured parameters. The differences were considered statistically significant when $P<0.05$. At least five observations were presented in each group. Data are represented graphically using box-and-whisker plots, which demonstrate the median, IQR, lower extreme (25\%) and upper extreme $(75 \%)$ of the data.

\section{Results}

\section{Expression of Hif-I $a$ and Nf- $\kappa b$ in the liver}

Three and six hours after the administration of LPS, the expression level of $N f-\kappa b$ in the liver increased only in the rats susceptible to hypoxia. In the animals tolerant to hypoxia, the increase was not significant (Figure 1).

After 24 hours, the level of expression of $N f-\kappa b$ was normal, but in the susceptible rats, it was higher than in the animals tolerant to hypoxia (Table 2).

Expression of Hif-1a in the control group of rats was significantly higher in the animals susceptible to hypoxia (Table 2). Six hours after the injection of LPS, Hif-1 $a$ expression increased in both tolerant and susceptible rats (Figure 2), and in susceptible animals, it was two times higher than in tolerant ones (Table 2). After 24 hours, the expression of
Hif- $1 \alpha$ returned to normal levels; but in the susceptible animals, it remained higher than in tolerant rats.

\section{Determination of cytokine content}

Based on the results of the enzyme immunoassay, it was demonstrated that the significant increase in the level of the proinflammatory cytokine IL- $1 \beta$ in the blood serum occurred after 3 hours of LPS administration only in the susceptible rats, while in the tolerant animals, the differences were not significant (Figure 3). After 6 hours in the rats susceptible to hypoxia, the serum levels of IL-1 $\beta$ were normalized; but after 24 hours, they remained significantly higher than in the tolerant rats (Table 3).

According to our data, only in the rats susceptible to hypoxia, the level of CRP (the marker of inflammation) in the blood was increased from 1,363 $(1,128-1,551 \mathrm{pg} / \mathrm{mL})$ in the control group to $2,421(1,810-2,844 \mathrm{pg} / \mathrm{mL})$ after 24 hours of LPS administration $(P=0.04)$.

In the animals tolerant to hypoxia, after 6 hours of LPS injection, the production of anti-inflammatory cytokine IL-10 in the spleen was significantly reduced, and 24 hours later, it was normalized and was statistically significantly higher than in the susceptible rats (Figure 4; Table 3).

In comparison with the control group, a significant decrease in serum TGF- $\beta$ level was observed after 24 hours of LPS administration only in the rats tolerant to hypoxia (Figure 5). In the susceptible rats, this parameter did not change. There were no statistically significant differences

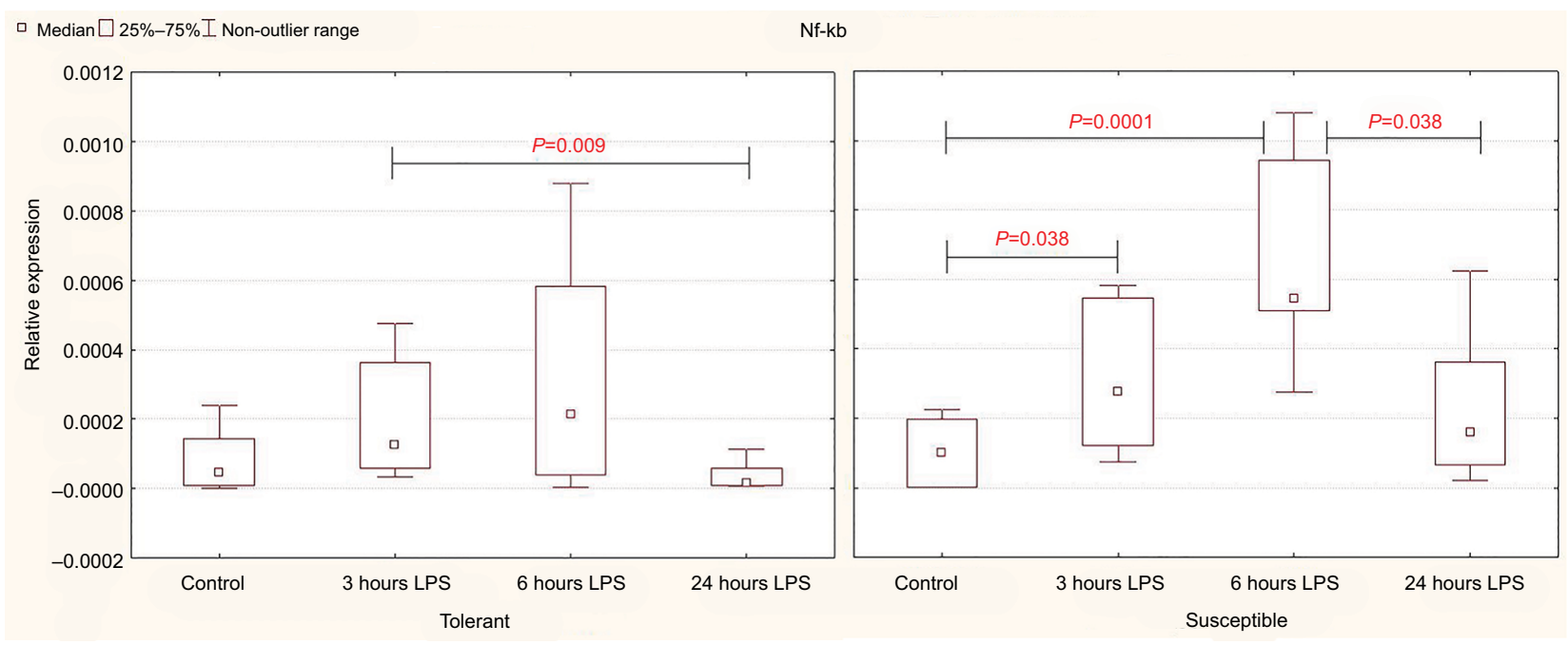

Figure I Expression of Nf- $\kappa b$ in the liver of rats tolerant and susceptible to hypoxia after 3, 6 and 24 hours of LPS administration (Me; $25 \%-75 \%$ ).

Notes: In all groups there were 5 observations except the tolerant group after 24 hours of LPS injection, in which were 8 . Statistical significance of differences ( $P$-value) is determined by the Kruskal-Wallis method.

Abbreviation: LPS, lipopolysaccharide. 


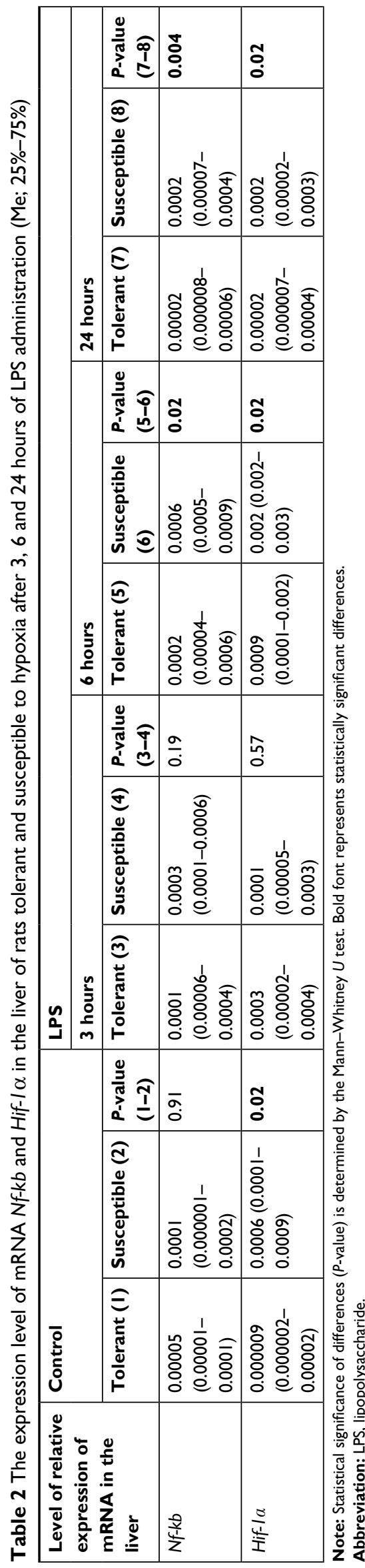

in the TGF- $\beta$ level between the tolerant and susceptible animals (Table 4).

\section{Morphological changes in the lungs}

In all the periods, after LPS injection in its target organ - the lungs - both in tolerant and susceptible rats, infiltration of interalveolar septa with neutrophils, hyperemia and intraalveolar edema was observed (Figure 6).

After 6 hours of LPS injection in the rats susceptible to hypoxia, the number of neutrophils in the interalveolar septa was significantly higher in comparison with the tolerant ones (Figure 7).

One day after the administration of LPS in animals of both groups, the number of neutrophils in the interalveolar septa did not differ from the control values.

All the results are summarized in Table 5.

\section{Discussion}

It is known that with the introduction of endotoxin of gramnegative bacteria LPS, the activation of TLR-4 receptors occurs, which leads to the initiation of IKK and the destruction of $\mathrm{I} \kappa \mathrm{B}$ in the proteasome, which causes increase in the expression of $\mathrm{NF}-\mathrm{KB}$ and its translocation into the nucleus. ${ }^{33,37,44,50} \mathrm{NF}-\mathrm{\kappa B}$ induces the production of proinflammatory cytokines, IL- $1 \beta$, TNF- $\alpha$ and IL- 6 , which stimulate the liver cells to synthesize acute inflammation proteins, including CRP, 4-6 hours after the exposure. ${ }^{51,52}$ In addition, LPS induces the synthesis of anti-inflammatory cytokines IL-10 as well as IL-4 and IL-13, which block the activation of NF- $\kappa B$ by the negative feedback mechanism. ${ }^{53}$

In our work, it was demonstrated that in the early periods after the injection of LPS, the increase in $N f-k b$ expression in the liver was observed only in rats susceptible to hypoxia. In tolerant animals, no significant differences from the control group were found at all the periods after the administration of LPS, and the expression level of $N f-k b$ after 6 and 24 hours of LPS injection was significantly lower than in susceptible rats. This indicates the development of more pronounced LPS-induced inflammation in rats susceptible to hypoxia. It is manifested by an increase of IL- $1 \beta$ in the blood that could be observed only in susceptible animals 3 hours after the administration of LPS. After 24 hours, its level was normalized in male rats susceptible to hypoxia, but remained higher than in animals tolerant to hypoxia.

According to the literature, in response to the administration of LPS, the level of CRP rises significantly after 10-12 hours and reaches a peak after $24-48$ hours. ${ }^{54-57}$ According to our data, a significant increase in CRP level 


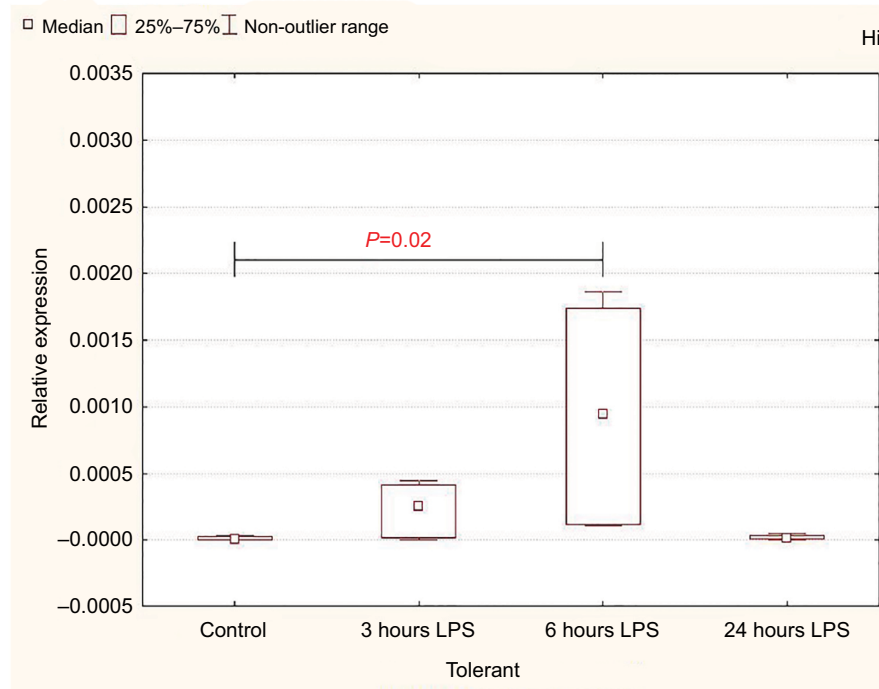

Hif-1a

Figure 2 Expression of $\mathrm{Hif}-\mathrm{I} \alpha$ in the liver of rats tolerant and susceptible to hypoxia after 3, 6 and 24 hours of LPS administration (Me; $25 \%-75 \%$ )

Notes: In all groups there were 5 observations except the tolerant group after 24 hours of LPS injection, in which were 8 . Statistical significance of differences ( $P$-value) is determined by the Kruskal-Wallis method.

Abbreviation: LPS, lipopolysaccharide.

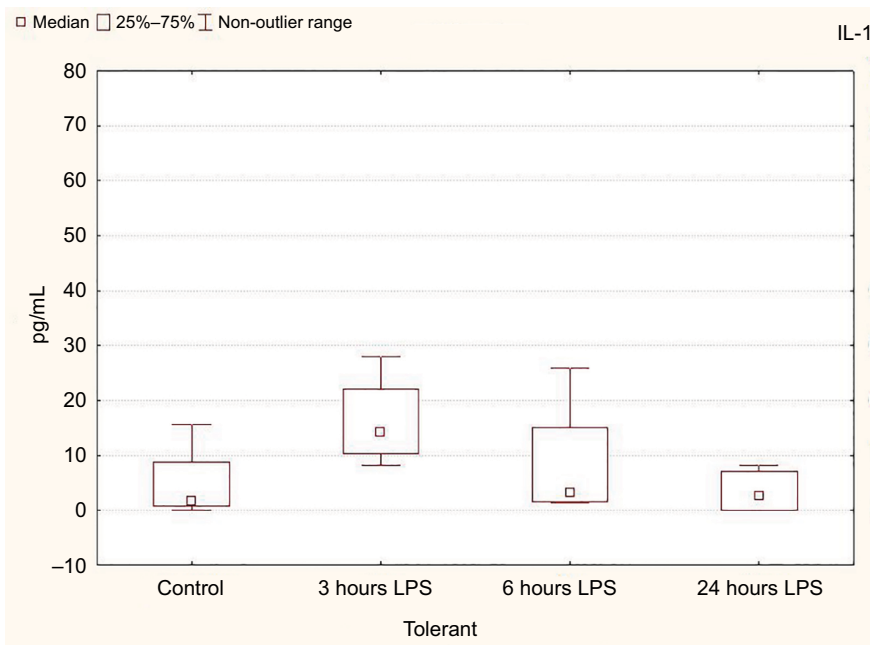

IL-1 $1 \beta$

Figure 3 Serum IL-I $\beta$ levels in rats tolerant and susceptible to hypoxia after 3, 6 and 24 hours of LPS administration (Me; 25\%-75\%).

Notes: In all groups there were 5 observations except the tolerant group after 24 hours of LPS injection, in which were 8 . Statistical significance of differences ( $P$-value) is determined by the Kruskal-Wallis method.

Abbreviation: LPS, lipopolysaccharide.

occurred in the blood serum after 24 hours only in rats susceptible to hypoxia. Probably, it was possible due to the activation of proinflammatory responses, indicated by increase in the level of IL-1 $\beta$ after 3 hours of LPS administration in these rats, since it is known that IL- $1 \beta$ promotes the synthesis of acute inflammation proteins. ${ }^{57,58}$ As the level of CRP synthesis reflects the intensity of the inflammatory process, it is used as one of the clinical markers of infectious and inflammatory diseases, including sepsis..$^{59,60}$ It was demonstrated that high concentrations of CRP in the development of sepsis indicate unfavorable prognosis. ${ }^{61}$ Therefore, rats susceptible to hypoxia are characterized by more pronounced inflammatory reaction in response to the administration of the LPS.

Apparently, greater sensitivity to the development of a systemic inflammatory response in animals susceptible to hypoxia is due to a high level of oxidative stress, ${ }^{28,32}$ since it is known that it plays an important role in the development of systemic inflammatory response. ${ }^{62}$ However, HIF- $1 \alpha$ may also participate in the development of a systemic inflammatory response and can be connected to its greater sensitivity to 


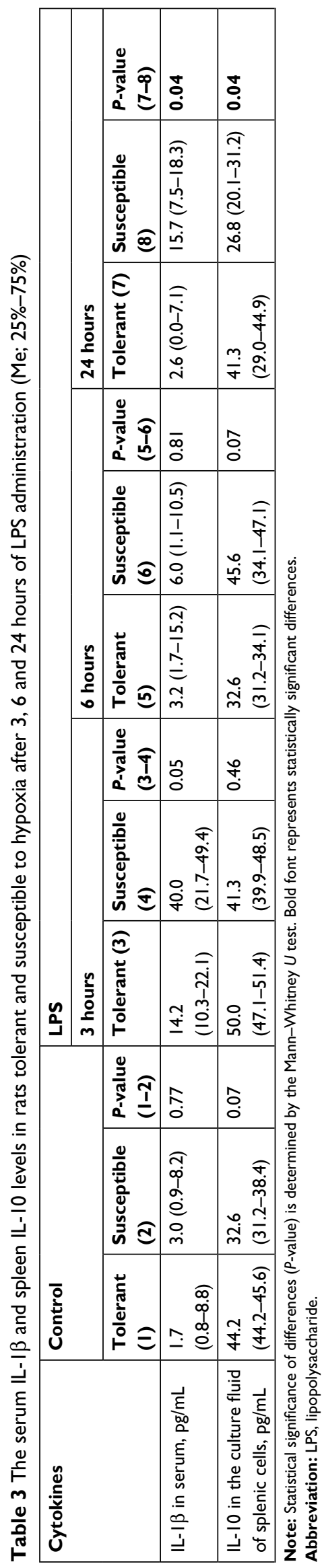

rats susceptible to hypoxia. Hyperactivation of the production of inflammatory molecules leads to a disturbance of hemodynamics, activation of coagulation with the increase of $\mathrm{NO}$ synthesis, vasoconstriction and the development of hypoxia, which also affects the immune cells. ${ }^{63}$ In 2006 , Frede et al demonstrated that LPS can induce the NF- $\mathrm{KB}$-dependent increase in mRNA and HIF- $1 \alpha$ protein levels. ${ }^{11}$ As it was mentioned before, in systemic infections such as sepsis, the increase in HIF- $1 \alpha$ levels results in greater mortality and enhancement in the levels of proinflammatory cytokines (IL-1 $\beta$, TNF $\alpha$ ) in the serum. ${ }^{19}$ In our study, the level of Hif- $1 \alpha$ expression was statistically significantly higher in rats susceptible to hypoxia from the control group than in rats tolerant to hypoxia, consistent with previous studies. ${ }^{27}$ This may indicate that animals susceptible to hypoxia are more predisposed to the development of inflammatory diseases. As it was discussed earlier, the situation in which HIF-1 is activated (hypoxia or inflammation) influences the result of this process. If HIF-1 is activated due to hypoxia, the transcription of various targeted genes is enhanced, which facilitates adaptation to the lack of oxygen. Being influenced by the TLR-4- and NF-KB-dependent pathways, the genes of proinflammatory cytokines become active. ${ }^{16}$ In our study, after 6 hours of LPS injection, the level of liver Hif- $1 \alpha$ expression increased significantly in both the rats susceptible and tolerant to hypoxia; however, the increase was twice higher in susceptible rats than in tolerant rats. Nevertheless, in tolerant rats, there was no increase in the level of expression of $N f-\kappa b$, which indicates that in these animals, HIF is activated independently from the NF- $\mathrm{KB}$ pathway and does not lead to a pronounced inflammatory reaction.

It is known that anti-inflammatory cytokines, such as IL-10 and TGF- $\beta$, produced by macrophages and peripheral mononuclear cells under the influence of LPS, regulate the development of the inflammatory response. IL-10 limits the inflammatory response, and TGF- $\beta$ plays an important role in suppressing the functional activity of immune cells. Antiinflammatory cytokines are able to inhibit the production of IL-1 and TNF $\alpha .{ }^{64,65}$ However, their excessive secretion can contribute to immunodeficiency, increased sensitivity to infections, subsequent development of secondary infections and chronic inflammation. ${ }^{66-68}$ We demonstrated that in rats tolerant to hypoxia, there was a significant decrease in the level of IL-10 after 6 hours and TGF- $\beta$ after 24 hours of LPS administration. According to the literature, the neutralization of IL-10 activity increases the survival rate of animals in the model of sepsis that developed against the background of pneumonias. ${ }^{69}$ A higher level of IL-10 is also observed 


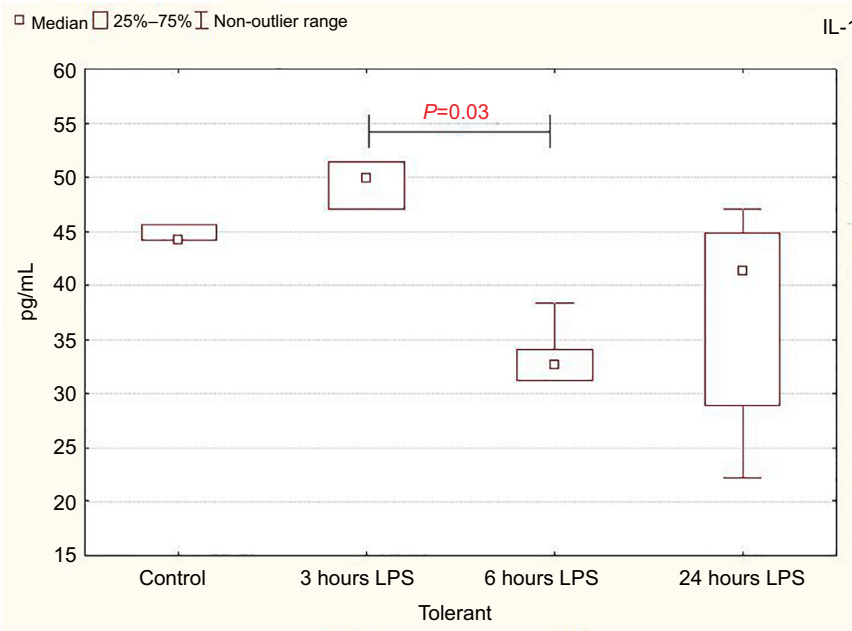

IL-10

Figure 4 IL- 10 production by spleen cells activated by Concanavalin A in rats tolerant and susceptible to hypoxia after 3, 6 and 24 hours of LPS administration (Me; $25 \%-75 \%$ ). Notes: In all groups there were 5 observations except the tolerant group after 24 hours of LPS injection, in which were 8 . Statistical significance of differences ( $P$-value) is determined by the Kruskal-Wallis method.

Abbreviation: LPS, lipopolysaccharide.

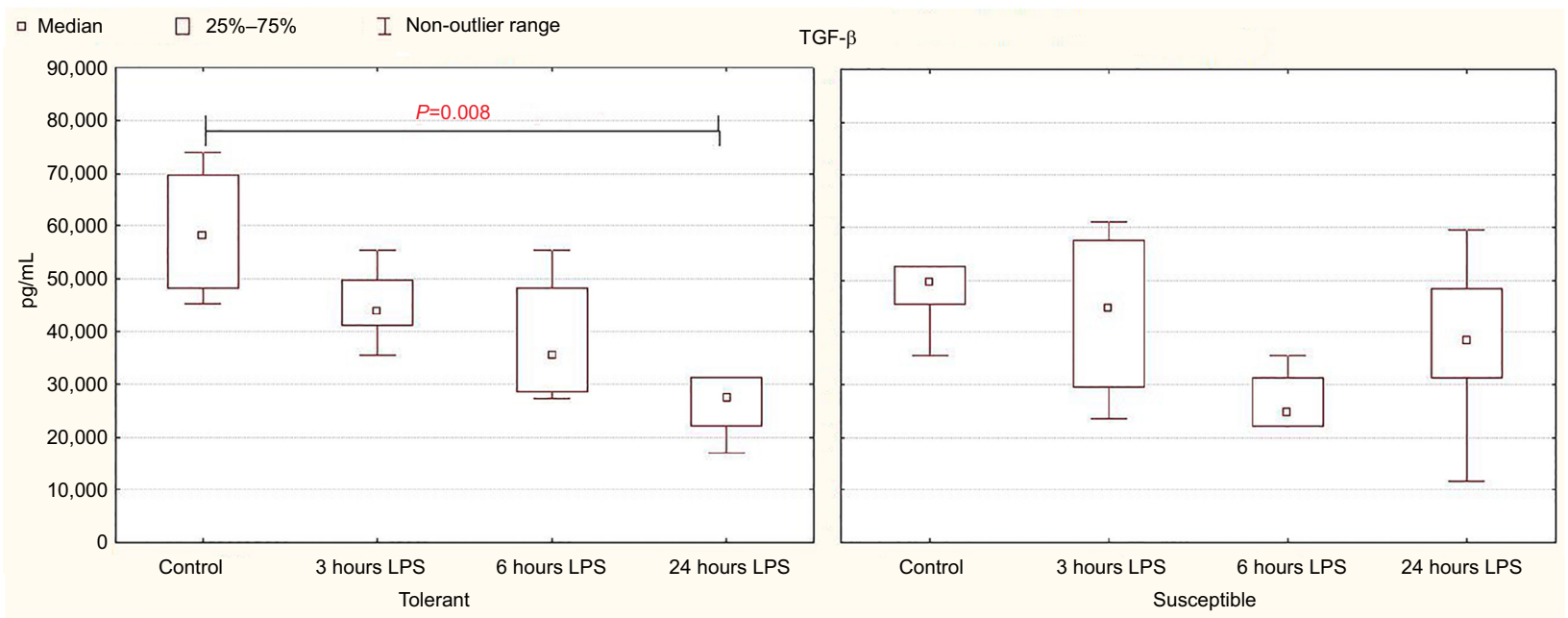

Figure 5 TGF- $\beta$ serum levels in rats tolerant and susceptible to hypoxia after 3, 6 and 24 hours of LPS administration (Me; 25\%-75\%).

Notes: In all groups there were 5 observations except the tolerant group after 24 hours of LPS injection, in which were 8 . Statistical significance of differences ( $P$-value) is determined by the Kruskal-Wallis method.

Abbreviation: LPS, lipopolysaccharide.

in patients with post-burn sepsis and a fatal outcome. ${ }^{70}$ Apparently, in rats tolerant to hypoxia, decrease in serum IL-10 levels after 6 hours and TGF- $\beta$ after 24 hours of LPS administration prevents immunosuppression and increases the survival rate of animals. In rats susceptible to hypoxia, the level of anti-inflammatory cytokines did not change, which indicates development of the intensive inflammatory reaction in response to the administration of LPS.

According to the literature, myeloid cells, including neutrophils and monocytes/macrophages, contain a variety of proteolytic enzymes and are able to rapidly generate the ROS to destroy pathogens. Thus, although neutrophils are important for the destruction of pathogens, their activation can cause a hyperimmune response and cellular damage during sepsis and other inflammatory diseases. ${ }^{39,71}$ Neutrophil-mediated damage to lung, liver and other organs has been manifested in sepsis. ${ }^{72,73}$ In our study, in comparison with rats tolerant to hypoxia, a higher number of neutrophils was observed in the interalveolar septa of the lungs in susceptible animals after 6 hours of 


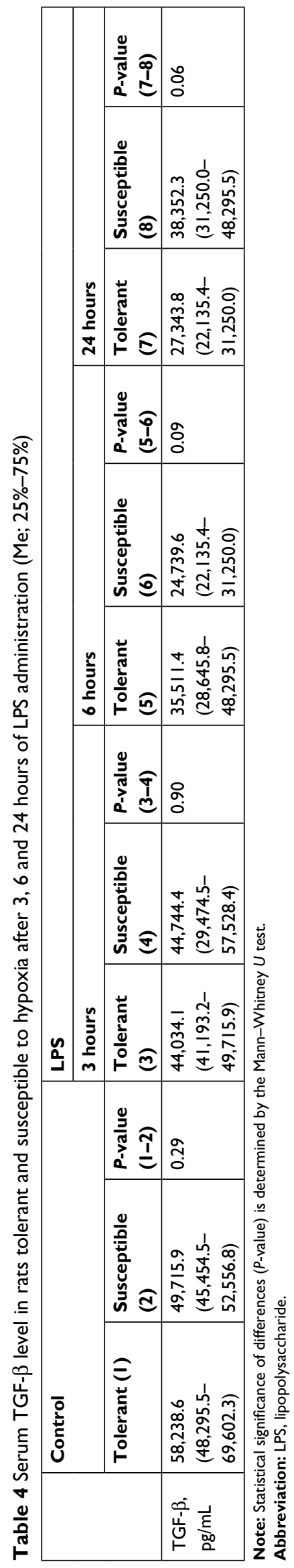

LPS injection, which may indicate more pronounced lung damage in these animals.

In studies of the possibility of using HIF-1 as a marker of inflammatory diseases and as a potential therapeutic target in humans, its expression level was examined, which may differ depending on the resistance to hypoxia. These studies were performed mainly on patients who already developed inflammatory disease, which prevents us from certainly concluding about the connection between inflammatory reactions and the initial resistance to hypoxia. In our experimental study, it was demonstrated that in response to the injection of LPS, HIF- $1 \mathrm{a}$ expression was more pronounced in animals susceptible to hypoxia, and they had a greater severity of the inflammatory response, as confirmed by higher levels of $N f-\kappa b$, CRP and IL-1 $\beta$. Therefore, modulation of the expression of HIF- $1 \alpha$ may have therapeutic value, especially in organisms that are susceptible to hypoxia.

As mentioned above, increased expression of HIF-1 can be both proinflammatory and anti-inflammatory, depending on the context of inflammation. Proinflammatory activation of HIF- $1 \alpha$ is demonstrated on the LPS-induced sepsis model, ${ }^{19}$ and anti-inflammatory activation is demonstrated on the colitis model. ${ }^{18} \mathrm{We}$ first showed that increased expression of HIF- $1 \alpha$ in systemic infections leads to a greater severity of the inflammatory response in animals susceptible to hypoxia. However, further studies are essential for the understanding of the possible protective role of increased expression of HIF-1 $\alpha$ in animals susceptible to hypoxia on a colitis model.

Along with the main therapy of infectious and inflammatory diseases, antioxidants and antihypoxants are often used, but their effectiveness varies between patients..$^{74,75}$ Their effectiveness can also be determined by the variability in the individual resistance to hypoxia. Considering our data that rats susceptible to hypoxia have more pronounced systemic inflammatory response, it can be assumed that the use of antihypoxants will reduce the severity of the inflammatory response. Indeed, in experimental studies it has been demonstrated that antihypoxic drugs, when used in combination with nonsteroidal anti-inflammatory drugs, significantly reduce the severity of inflammatory reactions. ${ }^{76,77}$ However, the effectiveness of such drugs may not be the same in individuals with different resistance to hypoxia. It is likely that the dose and course of treatment with antihypoxants should be selected taking into consideration the individual's resistance to hypoxia. In our opinion, the use of antihypoxants will be more effective in patients susceptible to hypoxia. Therefore, our data probably will 

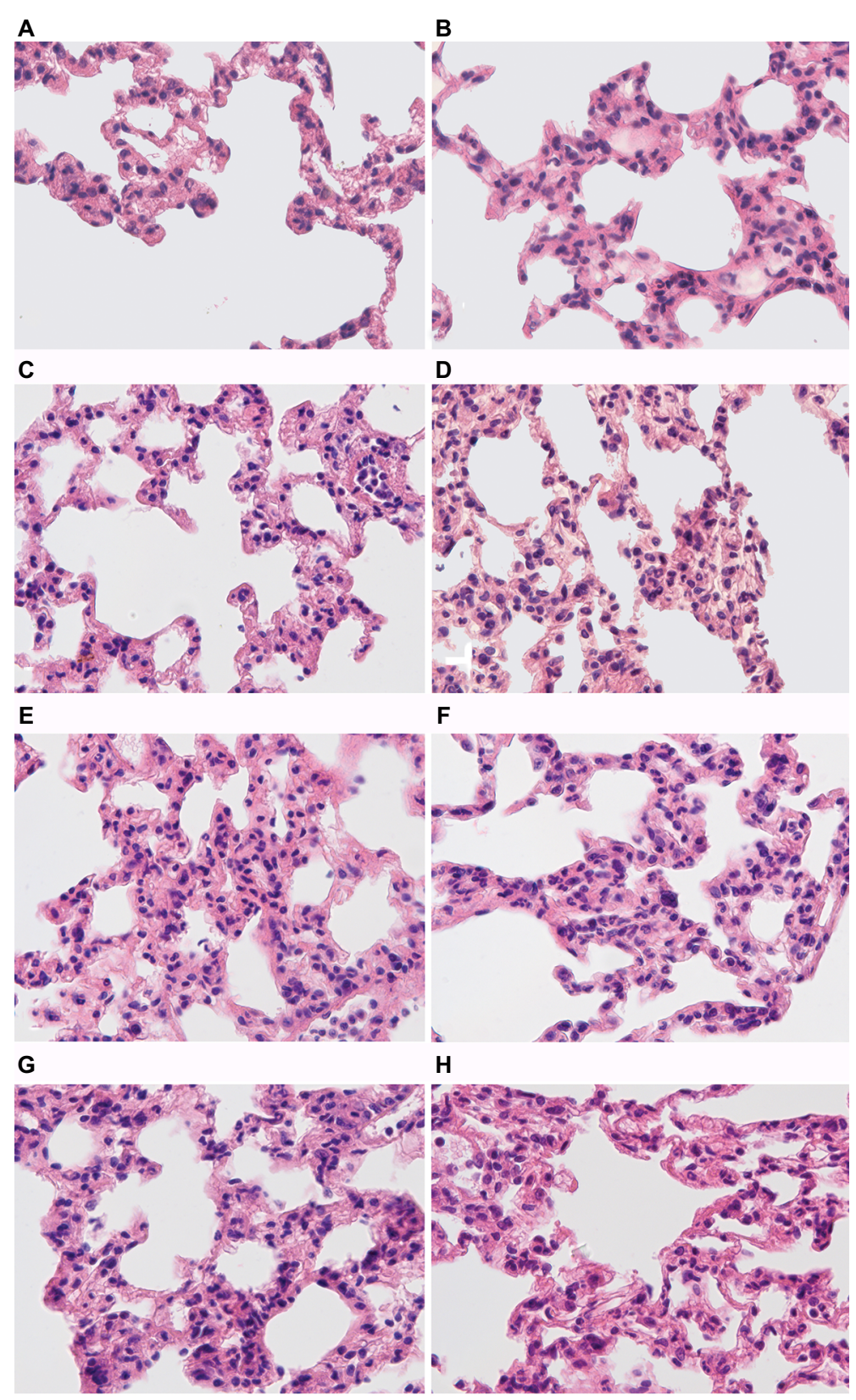

Figure 6 Morphological changes in the lungs of male Wistar rats tolerant and susceptible to hypoxia after 3, 6 and 24 hours of LPS administration.

Notes: H\&E staining. Original magnification: (A-H) 640×. (A) Rats tolerant to hypoxia, control group - few neutrophils in the field of view. (B) Rats susceptible to hypoxia, control group - few neutrophils in the field of view. (C) Rats tolerant to hypoxia, 3 hours LPS - thickened interalveolar septa with neutrophils, hyperemia. (D) Rats susceptible to hypoxia, 3 hours LPS - pronounced neutrophil infiltration in interalveolar septa, hyperemia. (E) Rats tolerant to hypoxia, 6 hours LPS - neutrophil infiltration in interalveolar septa, hyperemia. (F) Rats susceptible to hypoxia, 6 hours LPS - high number of neutrophils in interalveolar septa, hyperemia. (G) Rats tolerant to hypoxia, 24 hours LPS - interalveolar septa with neutrophils, hyperemia. (H) Rats susceptible to hypoxia, 24 hours LPS - interalveolar septa with neutrophils, hyperemia. Abbreviation: LPS, lipopolysaccharide.

allow to develop new approaches for personalized medicine, taking into consideration the individual's initial resistance to hypoxia.

Some authors use hypoxic preconditioning in experimental studies to increase the level of HIF-1, which improves adaptation to hypoxia. ${ }^{41,78}$ However, given the initially high level of expression of HIF-1 in rats susceptible to hypoxia, shown in our work and by other authors, ${ }^{27}$ its additional increase may, on the contrary, contribute to the predisposition to develop inflammatory processes. Therefore, in such studies, it is also necessary to take into consideration the results obtained in our work. 

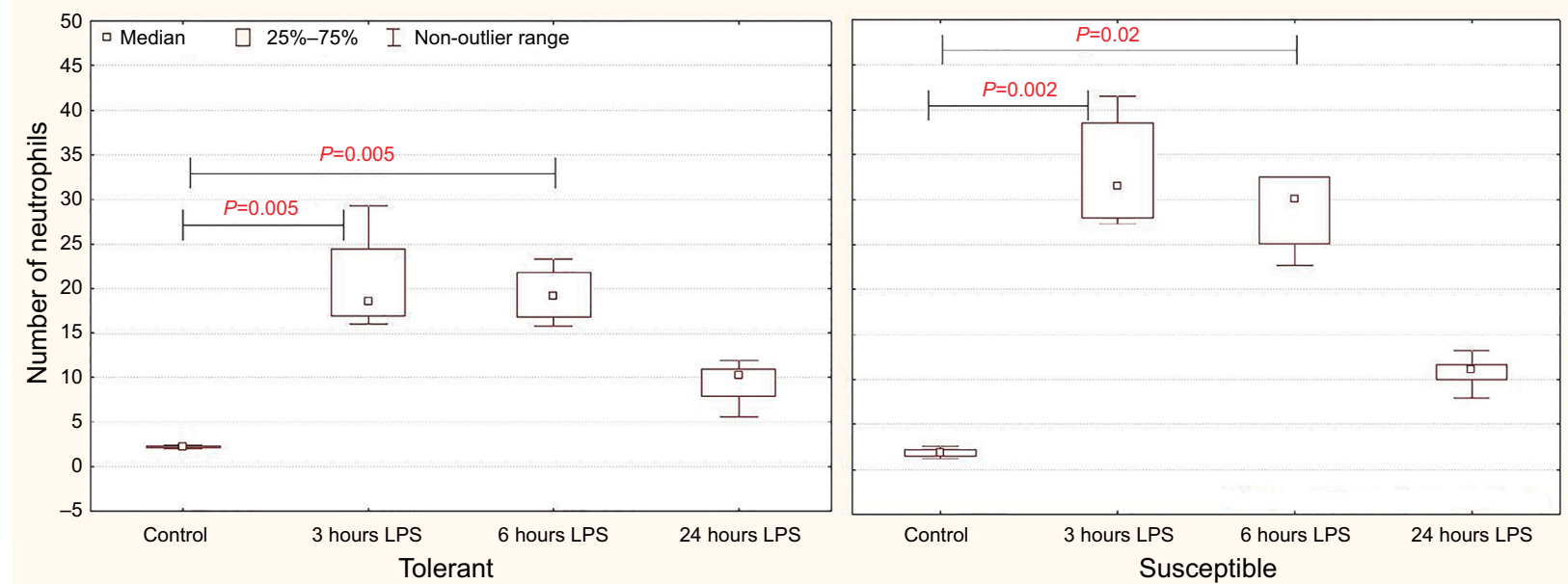

Figure 7 The average number of neutrophils counted in ten high-power fields of view $\left(25,000 \mu \mathrm{m}^{2}\right)$ per section in the interalveolar septa of the lungs of rats tolerant and susceptible to hypoxia after 3, 6 and 24 hours of LPS administration (Me; $25 \%-75 \%$ ).

Notes: In all groups there were 5 observations except the tolerant group after 24 hours of LPS injection, in which were 8 . Statistical significance of differences (P-value) is determined by the Kruskal-Wallis method.

Abbreviation: LPS, lipopolysaccharide.

Table 5 Summary of results

\begin{tabular}{|c|c|c|c|}
\hline Index & Organ & Tolerant & Susceptible \\
\hline mRNA Hif-I $\alpha$ & Liver & Increased after 6 hours of LPS injection & $\begin{array}{l}\text { Increased after } 6 \text { hours of LPS injection } \\
\text { In the control group, after } 6 \text { and } 24 \text { hours of LPS injection, it } \\
\text { was higher than in tolerant animals }\end{array}$ \\
\hline mRNA Nf-kb & & No changes & $\begin{array}{l}\text { Increased after } 3 \text { and } 6 \text { hours of LPS injection. After } 6 \text { and } 24 \\
\text { hours, it was higher than in tolerant animals }\end{array}$ \\
\hline IL-I $\beta$ & Serum & No changes & $\begin{array}{l}\text { Increased after } 3 \text { hours of LPS injection } \\
\text { After } 24 \text { hours, it was higher than in tolerant animals }\end{array}$ \\
\hline C-reactive protein & Serum & No changes & Increased after 24 hours of LPS injection \\
\hline IL- IO & $\begin{array}{l}\text { Culture fluid of } \\
\text { splenic cells }\end{array}$ & $\begin{array}{l}\text { Decreased after } 6 \text { hours of LPS injection } \\
\text { After } 24 \text { hours, it was higher than in the } \\
\text { susceptible animals }\end{array}$ & No changes \\
\hline TGF- $\beta$ & Serum & Decreased after 24 hours of LPS injection & No changes \\
\hline $\begin{array}{l}\text { Number of } \\
\text { neutrophils }\end{array}$ & Lungs & $\begin{array}{l}\text { Increased after } 3 \text { and } 6 \text { hours of LPS } \\
\text { injection }\end{array}$ & $\begin{array}{l}\text { Increased after } 3 \text { and } 6 \text { hours of LPS injection. After } 6 \text { hours, } \\
\text { it was higher than in tolerant animals }\end{array}$ \\
\hline
\end{tabular}

Abbreviation: LPS, lipopolysaccharide.

\section{Conclusion}

Thus, for the first time, the various expressions of SIRS in animals with different resistance levels to hypoxia are demonstrated here. Rats susceptible to hypoxia are characterized by a more pronounced inflammatory response induced by LPS, which is revealed by increased expression of $N f-k b$ and $H i f-1 \alpha$ in the liver, a greater number of neutrophils in the interalveolar septa of the lungs and an increased content of IL- $1 \beta$ and CRP. In tolerant animals, after 6 hours of LPS administration, the level of the anti-inflammatory cytokine IL-10 produced by splenic cells was reduced and after 24 hours, its level was higher than in susceptible rats. Twenty-four hours after the administration of LPS, a statistically significant decrease in serum TGF- $\beta$ level occurred in rats tolerant to hypoxia, which prevents immunodeficiency states and increases the survival rate of animals. The data will be the basis for further experimental investigations and the development of new approaches for treating infectious diseases.

\section{Acknowledgment}

We are grateful to Lokhonina AV, Elchaninov AV and Usman NY for their help in PCR. 


\section{Disclosure}

The authors report no conflicts of interest in this work.

\section{References}

1. Martin GS, Mannino DM, Eaton S, Moss M, et al. The epidemiology of sepsis in the United States from 1979 through 2000. N Engl J Med. 2003;348(16):1546-1554.

2. Esper AM, Moss M, Lewis CA, et al. The role of infection and comorbidity: factors that influence disparities in sepsis. Crit Care Med. 2006;34(10):2576-2582.

3. Mayr FB, Yende S, Angus DC. Epidemiology of severe sepsis. Virulence. 2014;5(1):4-11.

4. Semenza GL, Wang GL. A nuclear factor induced by hypoxia via de novo protein synthesis binds to the human erythropoietin gene enhancer at a site required for transcriptional activation. Mol Cell Biol. 1992;12(12):5447-5454.

5. Wenger RH, Stiehl DP, Camenisch G. Integration of oxygen signaling at the consensus HRE. Sci STKE. 2005;2005(306):re12.

6. Kaelin WG, Ratcliffe PJ. Oxygen sensing by metazoans: the central role of the HIF hydroxylase pathway. Mol Cell. 2008;30(4):393-402.

7. Hirota K. Involvement of hypoxia-inducible factors in the dysregulation of oxygen homeostasis in sepsis. Cardiovasc Hematol Disord Drug Targets. 2015;15(1):29-40.

8. Bonello S, Zähringer C, Belaiba RS, et al. Reactive oxygen species activate the HIF-1 $\alpha$ promoter via a functional NFKB site. Arterioscler Thromb Vasc Biol. 2007;27(4):755-761.

9. Rius J, Guma M, Schachtrup C, et al. NF-kappaB links innate immunity to the hypoxic response through transcriptional regulation of HIF1alpha. Nature. 2008;453(7196):807-811.

10. van Uden P, Kenneth NS, Rocha S. Regulation of hypoxia-inducible factor-1alpha by NF-kappaB. Biochem J. 2008;412(3):477-484.

11. Frede S, Stockmann C, Freitag P, Fandrey J, et al. Bacterial lipopolysaccharide induces HIF-1 activation in human monocytes via p44/42 MAPK and NF-кB. Biochem J. 2006;396(3):517-527.

12. Hellwig-Bürgel T, Rutkowski K, Metzen E, Fandrey J, Jelkmann W. Interleukin-1beta and tumor necrosis factor-alpha stimulate DNA binding of hypoxia-inducible factor-1. Blood. 1999;94(5):1561-1567.

13. Chandel NS, Mcclintock DS, Feliciano CE, et al. Reactive oxygen species generated at mitochondrial complex III stabilize hypoxia-inducible factor-1 alpha during hypoxia: a mechanism of $\mathrm{O}_{2}$ sensing. $\mathrm{J}$ Biol Chem. 2000;275(33):25130-25138.

14. Cummins EP, Berra E, Comerford KM, et al. Prolyl hydroxylase-1 negatively regulates IkappaB kinase-beta, giving insight into hypoxia-induced NFkappaB activity. Proc Natl Acad Sci USA. 2006;103(48):18154-18159.

15. Oliver KM, Taylor CT, Cummins EP. Hypoxia. Regulation of NFkappaB signalling during inflammation: the role of hydroxylases. Arthritis Res Ther. 2009;11(1):215.

16. Jantsch J, Wiese M, Schödel J, et al. Toll-like receptor activation and hypoxia use distinct signaling pathways to stabilize hypoxia-inducible factor $1 \alpha$ (HIF1A) and result in differential HIF1A-dependent gene expression. J Leukoc Biol. 2011;90(3):551-562.

17. Devraj G, Beerlage C, Brüne B, Kempf VA. Hypoxia and HIF-1 activation in bacterial infections. Microbes Infect. 2017;19(3):144-156.

18. Karhausen J, Furuta GT, Tomaszewski JE, et al. Epithelial hypoxiainducible factor-1 is protective in murine experimental colitis. J Clin Invest. 2004;114(8):1098-1106.

19. Peyssonnaux C, Cejudo-Martin P, Doedens A, et al. Cutting edge: essential role of hypoxia inducible factor-1alpha in development of lipopolysaccharide-induced sepsis. J Immunol. 2007;178(12):7516-7519.

20. Textoris J, Beaufils N, Quintana G, et al. Hypoxia-inducible factor $(\mathrm{HIF} 1 \alpha)$ gene expression in human shock states. Crit Care. 2012;16(4): R120.

21. Lorenzo VF, Yang Y, Simonson TS, et al. Genetic adaptation to extreme hypoxia: study of high-altitude pulmonary edema in a three-generation Han Chinese family. Blood Cells Mol Dis. 2009;43(3):221-225.
22. Kobayashi N, Hanaoka M, Droma Y, et al. Polymorphisms of the tissue inhibitor of metalloproteinase 3 gene are associated with resistance to high-altitude pulmonary edema (HAPE) in a Japanese population: a case control study using polymorphic microsatellite markers. PLoS One. 2013;8(8):e71993.

23. De Carvalho Fraga CA, Alves LR, Marques-Silva L, et al. High HIF- $1 \alpha$ expression genotypes in oral lichen planus. Clin Oral Investig. 2013;17(9):2011-2015.

24. Strauss E, Waliszewski K, Oszkinis G, Staniszewski R. Polymorphisms of genes involved in the hypoxia signaling pathway and the development of abdominal aortic aneurysms or large-artery atherosclerosis. J Vasc Surg. 2015;61(5):1105-1113.

25. Paradowska-Gorycka A, Stypinska B, Pawlik A, et al. HIF-1a gene polymorphisms and its protein level in patients with rheumatoid arthritis: a case-control study. Inflamm Res. 2018;67(5):423-433.

26. Yu ZG, Wang BZ, Cheng ZZ. The association of genetic polymorphisms of hypoxia inducible factor-1 alpha and vascular endothelial growth factor with increased risk of chronic obstructive pulmonary disease: a case-control study. Kaohsiung J Med Sci. 2017;33(9):433-441.

27. Kirova YI, Germanova EL, Lukyanova LD. Phenotypic features of the dynamics of HIF-1 $\alpha$ levels in rat neocortex in different hypoxia regimens. Bull Exp Biol Med. 2013;154(6):718-722.

28. Jain K, Suryakumar G, Prasad R, Ganju L. Upregulation of cytoprotective defense mechanisms and hypoxia-responsive proteins imparts tolerance to acute hypobaric hypoxia. High Alt Med Biol. 2013;14(1):65-77.

29. Tregub P, Kulikov V, Bespalov A. Tolerance to acute hypoxia maximally increases in case of joint effect of normobaric hypoxia and permissive hypercapnia in rats. Pathophysiology. 2013;20(3):165-170.

30. Lukyanova LD, Germanova EL, Kopaladze RA. Development of resistance of an organism under various conditions of hypoxic preconditioning: role of the hypoxic period and reoxygenation. Bull Exp Biol Med. 2009;147(4):400-404.

31. Serebrovskaya TV, Xi L. Individualized intermittent hypoxia training: principles and practices. In: Xi L, Serebrovskaya T, editors. Hypoxia and Human Diseases. London: Springer; 2012.

32. Dzhalilova DS, Diatroptov ME, Tsvetkov IS, et al. Expression of HIF- $1 \alpha$, NF- $\kappa B$ and VEGF genes in the liver and the content of HIF- $1 \alpha$, erythropoietin, VEGF, TGF- $\beta$, 8-isoprostane and corticosterone in the blood serum in tolerant and susceptible to hypoxia Wistar rats. Bull Exp Biol Med. 2018;165(6):781-785.

33. Chow JC, Young DW, Golenbock DT, Christ WJ, Gusovsky F. Toll-like receptor-4 mediates lipopolysaccharide-induced signal transduction. $J$ Biol Chem. 1999;274(16):10689-10692.

34. Lu YC, Yeh WC, Ohashi PS. LPS/TLR4 signal transduction pathway. Cytokine. 2008;42(2):145-151.

35. Ulevitch RJ, Tobias PS. Recognition of gram-negative bacteria and endotoxin by the innate immune system. Curr Opin Immunol. 1999;11(1):19-22.

36. Aderem A, Ulevitch RJ. Toll-like receptors in the induction of the innate immune response. Nature. 2000;406(6797):782-787.

37. Cinel I, Opal SM. Molecular biology of inflammation and sepsis: a primer. Crit Care Med. 2009;37(1):291-304.

38. Kosyreva AM, Simonova EY, Makarova OV. Gender differences in pulmonary and immune response in acute experimental endotoxicosis. Bull Exp Biol Med. 2012;153(3):340-342.

39. Fang H, Jiang W, Cheng J, et al. Balancing innate immunity and inflammatory state via modulation of neutrophil function: a novel strategy to fight sepsis. J Immunol Res. 2015;2015:187048.

40. Bhatia B, Thomas S, Purkayastha SS. Seasonal variations in the survival index of rats at simulated high altitudes. Int J Biometeorol. 1966;10(1):63-69.

41. Shrivastava K, Ram MS, Bansal A, Singh SS, Ilavazhagan G. Cobalt supplementation promotes hypoxic tolerance and facilitates acclimatization to hypobaric hypoxia in rat brain. High Alt Med Biol. 2008;9(1):63-75.

42. Lukyanova LD, Kirova YI. Effect of hypoxic preconditioning on free radical processes in tissues of rats with different resistance to hypoxia. Bull Exp Biol Med. 2011;151(3):292-296. 
43. Gautier EL, Huby T, Saint-Charles F, et al. Enhanced dendritic cell survival attenuates lipopolysaccharide-induced immunosuppression and increases resistance to lethal endotoxic shock. J Immunol. 2008;180(10):6941-6946.

44. Blackwell TS, Yull FE, Chen CL, et al. Multiorgan nuclear factor kappa $\mathrm{B}$ activation in a transgenic mouse model of systemic inflammation. Am J Respir Crit Care Med. 2000;162(3 Pt 1):1095-1101.

45. Pisarev VB, Novochadov VV, Bogomolova NV. Bacterial Endotoxicosis: Pathologist's View. Volgograd: Volgograd State Medical University; 2008. Russian.

46. Pfaffl MW. A new mathematical model for relative quantification in real-time RT-PCR. Nucleic Acids Res. 2001;29(9):e45.

47. Parasuraman S, Raveendran R, Kesavan R. Blood sample collection in small laboratory animals. $J$ Pharmacol Pharmacother. 2010;1(2): $87-93$.

48. Lin K-H, Lin K-C, Lu W-J, et al. Astaxanthin, a carotenoid, stimulates immune responses by enhancing IFN- $\gamma$ and IL-2 secretion in primary cultured lymphocytes in vitro and ex vivo. Int J Mol Sci. 2016;17(1):44.

49. Yamada M, Kubo H, Kobayashi S, et al. The increase in surface CXCR4 expression on lung extravascular neutrophils and its effects on neutrophils during endotoxin-induced lung injury. Cell Mol Immunol. 2011;8(4):305-314.

50. Seeley JJ, Ghosh S. Tolerization of inflammatory gene expression. Cold Spring Harb Symp Quant Biol. 2013;78:69-79.

51. Cannon JG, Tompkins RG, Gelfand JA, et al. Circulating interleukin-1 and tumor necrosis factor in septic shock and experimental endotoxin fever. J Infect Dis. 1990;161(1):79-84.

52. Esteban E, Ferrer R, Alsina L, Artigas A. Immunomodulation in sepsis: the role of endotoxin removal by polymyxin B-immobilized cartridge. Mediators Inflamm. 2013;2013(7):1-12.

53. Wang P, Wu P, Siegel MI, Egan RW, Billah MM. Interleukin (IL)-10 inhibits nuclear factor kappa B (NF kappa B) activation in human monocytes. IL-10 and IL-4 suppress cytokine synthesis by different mechanisms. J Biol Chem. 1995;270(16):9558-9563.

54. Ng PC, Cheng SH, Chui KM, et al. Diagnosis of late onset neonatal sepsis with cytokines, adhesion molecule, and C-reactive protein in preterm very low birthweight infants. Arch Dis Child Fetal Neonatal Ed. 1997;77(3):F221-F227.

55. Makhoul IR, Yacoub A, Smolkin T, et al. Values of C-reactive protein, procalcitonin, and Staphylococcus-specific PCR in neonatal late-onset sepsis. Acta Paediatr. 2006;95(10):1218-1223.

56. Hofer N, Zacharias E, Müller W, Resch B. An update on the use of C-reactive protein in early-onset neonatal sepsis: current insights and new tasks. Neonatology. 2012;102(1):25-36.

57. Slaats J, Ten Oever J, van de Veerdonk FL, Netea MG. IL-1//IL-6/CRP and IL-18/ferritin: distinct inflammatory programs in infections. PLoS Pathog. 2016;12(12):e1005973.

58. Kramer F, Torzewski J, Kamenz J, et al. Interleukin-1beta stimulates acute phase response and C-reactive protein synthesis by inducing an NFkappaB- and C/EBPbeta-dependent autocrine interleukin-6 loop. Mol Immunol. 2008;45(9):2678-2689.

59. Vigushin DM, Pepys MB, Hawkins PN. Metabolic and scintigraphic studies of radioiodinated human C-reactive protein in health and disease. J Clin Invest. 1993;91(4):1351-1357.
60. Póvoa P, Souza-Dantas VC, Soares M, Salluh JF. C-reactive protein in critically ill cancer patients with sepsis: influence of neutropenia. Crit Care. 2011;15(3):R129.

61. Beltempo M, Viel-Thériault I, Thibeault R, Julien AS, Piedboeuf B. $\mathrm{C}$-reactive protein for late-onset sepsis diagnosis in very low birth weight infants. BMC Pediatr. 2018;18(1):16.

62. Macdonald J, Galley HF, Webster NR. Oxidative stress and gene expression in sepsis. Br J Anaesth. 2003;90(2):221-232.

63. Cohen J. The immunopathogenesis of sepsis. Nature. 2002;420(6917): 885-891.

64. Sanjabi S, Zenewicz LA, Kamanaka M, Flavell RA. Anti-inflammatory and pro-inflammatory roles of TGF-beta, IL-10, and IL-22 in immunity and autoimmunity. Curr Opin Pharmacol. 2009;9(4):447-453.

65. Castellheim A, Brekke OL, Espevik T, Harboe M, Mollnes TE. Innate immune responses to danger signals in systemic inflammatory response syndrome and sepsis. Scand J Immunol. 2009;69(6):479-491.

66. Opal SM, Depalo VA. Anti-inflammatory cytokines. Chest. 2000;117(4):1162-1172.

67. Cavaillon JM, Annane D. Compartmentalization of the inflammatory response in sepsis and SIRS. J Endotoxin Res. 2006;12(3):151-170.

68. Couper KN, Blount DG, Riley EM. IL-10: the master regulator of immunity to infection. J Immunol. 2008;180(9):5771-5777.

69. van der Poll T, Marchant A, Keogh CV, Goldman M, Lowry SF. Interleukin-10 impairs host defense in murine pneumococcal pneumonia. $J$ Infect Dis. 1996;174(5):994-1000.

70. Yeh FL, Lin WL, Shen HD. Changes in circulating levels of an antiinflammatory cytokine interleukin 10 in burned patients. Burns. 2000;26(5):454-459.

71. Brown KA, Brain SD, Pearson JD, et al. Neutrophils in development of multiple organ failure in sepsis. Lancet. 2006;368(9530): $157-169$.

72. Kabay B, Kocaefe C, Baykal A, et al. Interleukin-10 gene transfer: prevention of multiple organ injury in a murine cecal ligation and puncture model of sepsis. World J Surg. 2007;31(1):105-115.

73. Stehr SN, Knels L, Weissflog C, et al. Effects of IGM-enriched solution on polymorphonuclear neutrophil function, bacterial clearance, and lung histology in endotoxemia. Shock. 2008;29(2):167-172.

74. Zarubina IV, Yunusov IA, Marysheva VV, Shabanov PD. Comparative efficiency of succinate-containing antihypoxants in traumatic toxicosis. Bull Exp Biol Med. 2010;150(2):212-214.

75. Bar-Or D, Carrick MM, Mains CW, et al. Sepsis, oxidative stress, and hypoxia: are there clues to better treatment? Redox Rep. 2015;20(5):193-197.

76. Fateeva EI, Mitrochin NM, Sernov LN. Study protective propertie of mexidol and new derivative 3-hydroxypyridine in combination with NSAIDs. Kubanskii Nauchnyi Meditsinskii Vestnik. 2008;6:78-83.

77. Pogilova EV. Influence of antihypoxants on the development of carrageenin-induced inflammation. I.P. Pavlov Russian Med Biol Herald. 2014;22(4):61-67.

78. Shukla D, Saxena S, Jayamurthy P, et al. Hypoxic preconditioning with cobalt attenuates hypobaric hypoxia-induced oxidative damage in rat lungs. High Alt Med Biol. 2009;10(1):57-69.
Journal of Inflammation Research

\section{Publish your work in this journal}

The Journal of Inflammation Research is an international, peer-reviewed open access journal that welcomes laboratory and clinical findings on the molecular basis, cell biology and pharmacology of inflammation including original research, reviews, symposium reports, hypothesis formation and commentaries on: acute/chronic inflammation; mediators of

\section{Dovepress}

inflammation; cellular processes; molecular mechanisms; pharmacology and novel anti-inflammatory drugs; clinical conditions involving inflammation. The manuscript management system is completely online and includes a very quick and fair peer-review system. Visit http://www.dove press.com/testimonials.php to read real quotes from published authors. 